\title{
Molecular Docking and Molecular Dynamic Simulation of 1,5-Benzothiazepine Chalcone Derivative Compounds as Potential Inhibitors for Zika Virus Helicase
}

\author{
Neni Frimayanti ${ }^{*}$, Musyirna Rahmah Nasution'1, Elsa Etavianti ${ }^{1}$ \\ 1Sekolah Tinggi Ilmu Farmasi Riau, Pekanbaru, Riau 28293, Indonesia
}

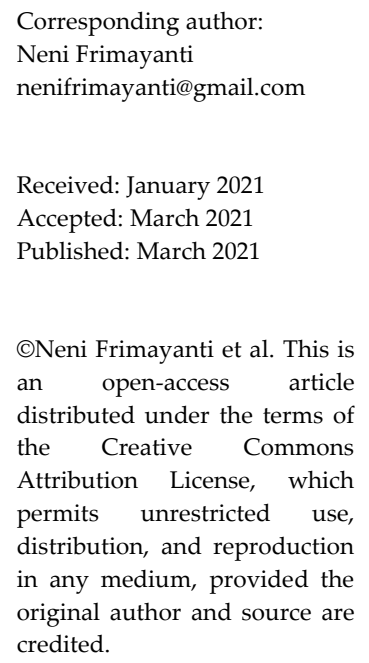

Received: January 2021 Accepted: March 2021 Published: March 2021

CNeni Frimayanti et al. This is an open-access article distributed under the terms of the Creative Commons Attribution License, which permits unrestricted use, distribution, and reproduction in any medium, provided the original author and source are credited.

\begin{abstract}
Zika virus caused of the emerging infections characterized by fever, GuillainBarré syndrome (GBS) for adults. In the current work, we aimed to study the binding orientation of 1,5-benzothiazepine compounds as new potential agent against Zika virus inhibitor through molecular docking and molecular dynamic simulation. Since, 1-5-Benzothiazepines are particular interest for drug discovery and they also has some biological activities. However, their antiviral activities and in silico studies of the binding to their biological targets have not been extensively investigated. Molecular docking study of 1,5benzothiazepine chalcone derivatives compounds with protein target 5GJB (PDB ID) and this protein was taken from the crystallographic structure. In this study, twelve 1,5-benzothiazepine chalcone derivative compounds were docked to the protein with the grid box along $\mathrm{x}$, $\mathrm{y}$ and $\mathrm{z}$ radius of $26.85,28.17$ and $24.43 \AA$, respectively. Suramin was used as positive control. Thus, it can be used as a reference for design new inhibitors for Zika virus helicase. Based on the docking results, it is observed that compounds MA3 and MA8 are estimated to have activity as inhibitors for Zika virus helicase with binding free energy values of -4.6490 and $-4.9291 \mathrm{kcal} / \mathrm{mol}$, respectively. MA3 and MA8 were also stable during the MD simulations with the hydrogen bonding are still maintained before and after MD simulation. Furthermore, both of these compounds can be used an early stage for drug design and drug delivery process.
\end{abstract}

Keywords: docking, MD simulation, 1,5-benzothiazepine, Zika virus, suramin

\section{Introduction}

Zika virus (ZIKV) is a type of Arbovirus from the genus Flavivirus. This virus has a relationship with other Arboviruses like Dengue, Yellow Fever, Japanese Encephalitis, and West Nile Virus. This virus was first isolated in 1947 from saliva of a monkey in a study of Yellow Fever ${ }^{[1]}$. There are some reports reported about the infections of Zika virus, one of them reported that in vitro studies on fibroblasts exposed to Zika virus shown high rates of infection from 24 to 48 hours after the onset of infection [2]. Some symptoms were shown such as rash, fever, conjunctivitis, myalgia, arthralgia, weakness, and headaches ${ }^{[1]}$.

Tan et. al reported that suramin was used as potential ZIKV infection in Vero cells. Unfortunately, De-sulfated heparin analogues lose the inhibitory effect, this may cause that sulfonate group are critical for viral inhibition. In addition, the inhibitory effect of glycosaminoglycans and analogues against 
ZIKV infection ${ }^{[3]}$. Thus, there are no reports about vaccine for this virus and there is also no approved vaccine that can be used to attack this Zika virus until now. Since there are no vaccine to attack this ZIKV, patient has been treated using their immune responses ${ }^{[4]}$.

1,5-benzothiazepine chalcone has been synthesized by previous researcher ${ }^{[5]}$ derivative compound consisted of seven-loop heterocyclic compound containing nitrogen and sulfur ${ }^{[6]}$. 1,5benzothiazepine chalcone derivative compound is a compound that has some biological activities such as antimicrobial[7]-[9], an anticonvulsant agent[10], Plasmodium falciparum cytochrome bc1 inhibitors[11], anti-HIV[12] and pulmonary anticancer $^{[13]}$. However, the antiviral activities like Zika virus inhibitor have not been extensively investigated.

The number of structural as well as nonstructural protein from ZIKV that have enzymatic function. The drug design and drug discovery was used the enzymatic resolution at high resolution as the main target. NS3 helicase is one of the enzymatic function, its was able inhibition in ZIKV makes the virus unable to replicate and duplicate ${ }^{[14]}$. Furthermore, in this research we used NS3 helicase with PDB ID $5 \mathrm{GJB}$ as the main target for ZIKV.

Rationally, the main goal is to explore the potency of 1,5-benzothiazepine chalcone derivative compounds to bind with the active site of the Zika virus helicase receptor. In silico study such as molecular docking and molecular dynamic simulation (MD) are able to identify the promising compounds with high activity and also less toxicity according to the binding free energy value ${ }^{[15]}$. To date, chalcone derivative heterocycles like 1,5-benzothiazepine chalcone derivative compounds have not extensively studied for the Zika virus inhibitors. In addition, there are not many reports about discovering new inhibitors for Zika virus using computational like molecular docking and MD simulation. The aim of this study is to determine the potentiality of the 1,5-benzothiazepine chalcone derivative compounds as new inhibitors for Zika virus helicase using molecular docking and MD simulation with suramin as a positive control.

\section{Experimental}

\section{Materials}

The computational research was performed using computer LG Intel(R) Core (TM) i7-8700 CPU, $3.20 \mathrm{GHz}$, with 16,0 GB of RAM, ChemDraw Professional 15.0, Molecular Operating Environment (MOE 2019.0101, CCG), Windows 10. Twelve of 1,5-benzothiazepine chalcone derivative compounds ${ }^{[5]}$, protein target $5 \mathrm{GJB}^{[16]}$ from modeling helicase enzyme crystallographic, and suramin was used as a positive control.

\section{Methods}

\section{Ligand preparation}

The molecular structure of twelve 1,5benzothiazepine has been synthesized ${ }^{[5]}$ and suramin were sketched using ChemDraw Professional software thus, saved with .cdx format and then converted into $\mathrm{pdb}$ format using discovery studio visualizer (DSV, Biovia) software package. The molecular structures of twelve 1,5-benzothiazepine chalcone derivative compounds and suramin are depicted in Table 1.

\section{Protein preparation}

Three-dimensional structures of 5GJB were obtained from the protein databank (www.rscb.org) in the .pdb. format with resolution of $1.7 \AA$. Then, the initial ligand and water molecules should be removed. Next is adding hydrogen atoms and energy minimization. The last stage is fixed the energy minimization for backbone atoms and also alpha carbons. Protein was prepared using MOE 2019.01 (Chemical computing group) software package. 
Tabel 1. Molecular structure of the ligand

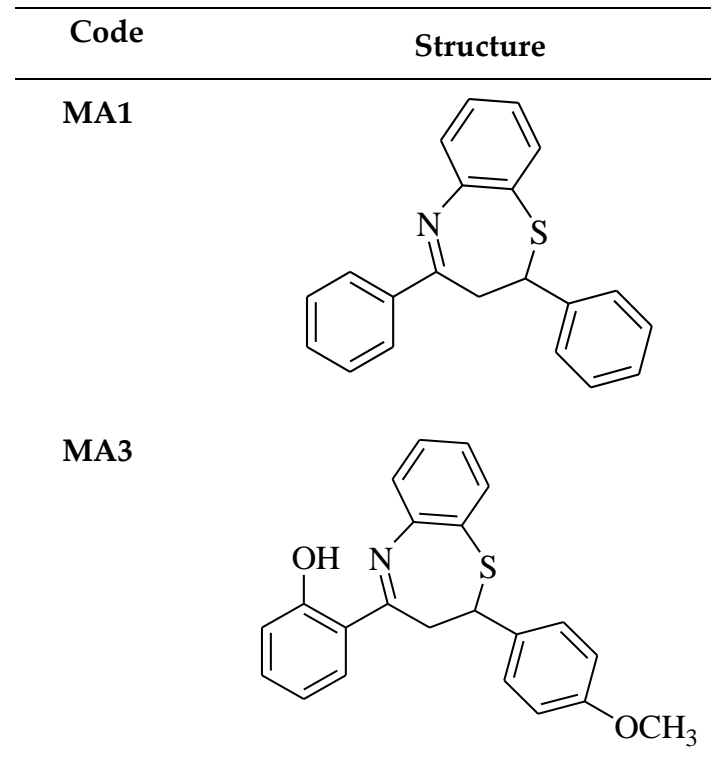

MA5<smiles>Cc1ccc(C2CC(c3ccccc3O)=Nc3ccccc3S2)cc1</smiles>

MA6<smiles>Oc1ccccc1C1=Nc2ccccc2SC(c2ccc3c(c2)OCO3)C1</smiles>

MA7<smiles>Oc1ccccc1C1=Nc2ccccc2SC(c2ccc(F)cc2)C1</smiles>

MA8<smiles>Oc1ccccc1C1=Nc2ccccc2SC(c2ccc(Cl)cc2)C1</smiles>

MA9<smiles>COc1ccc(C2=Nc3ccccc3SC(c3ccc4ccccc4c3)C2)cc1</smiles>

MA10<smiles>COc1ccc(C2CC(c3c(O)cc(OC)cc3OC)=Nc3ccccc3S2)cc1</smiles>

MA11<smiles>Cc1ccc(C2=Nc3ccccc3SC(c3ccc(F)cc3)C2)cc1</smiles>

MA12<smiles>Nc1ccc(C2=Nc3ccccc3SC(c3ccc(Cl)cc3Cl)C2)cc1</smiles> 


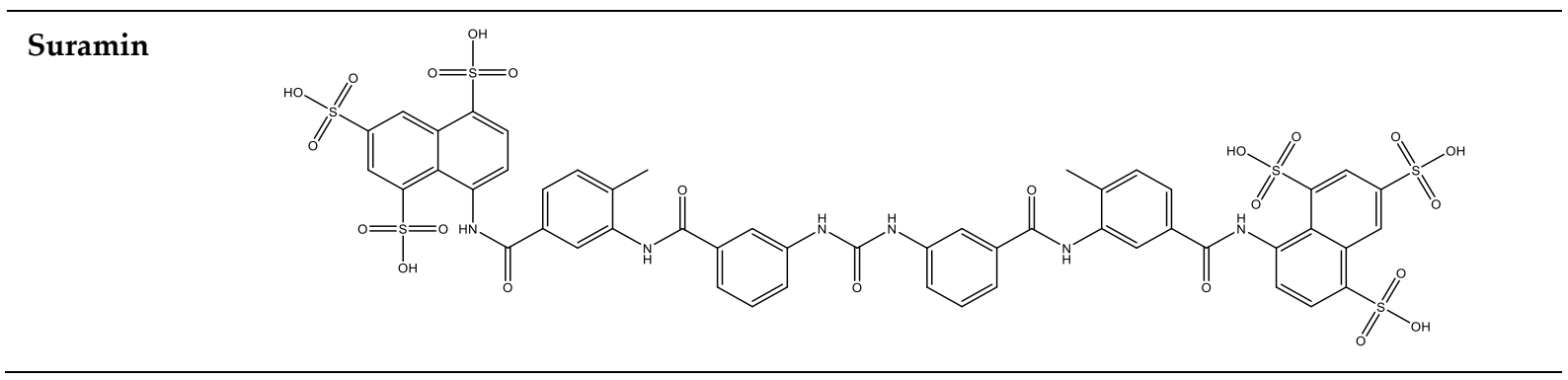

\section{Molecular docking}

Molecular docking was performed using MOE 2019.01 (Chemical computing group). It was begun with set up some docking parameters, CHARMM27 (Chemistry HARvard Macromolecular Mechanics) was selected as force field. The dimension along $x, y$ and $z$ radius were set up to be $26.85,28.17$ and $24.43 \AA$, respectively. The lowest binding free energy was selected as the best docking conformation from all the emerged results.

\section{Molecular dynamic simulation}

MD simulation was performed for 1,5benzothiazepine chalcone derivative compounds-protein complexes using NAMD (Nanoscale Molecular Dynamics program v 2.9) software package. In this case, CHARMM27 was selected as the best force field. Modeled protein was achieved for each direction of coordinated structure using TIP3P water box with the distances of $2.5 \AA$.

The system was heated using NVT ensemble from 0 to $300 \mathrm{~K}$ over $100 \mathrm{ps}$. Time scale was set up for $50 \mathrm{~ns}$ for each system in an isothermal isobaric ensemble (NPT) in periodic boundary conditions. Temperature and pressure were set as a coupling for $1.0 \mathrm{ps}$. Conformation of each coordinates were then saved every 0.1 ps during the sampling process. From this simulation, some conformations were generated for then the best conformation was selected for further binding free energy calculation.

\section{Results and Discussion}

Docking plays an important role in the rational drug design which are often used to predict the appropriate orientation and binding site of small molecule to their target protein to ascertain their affinity and activity[17]. Molecular docking has the advantage of filtering large compound databases at a relatively lower cost compared than experimental methods, it is also timesaving, cost-effective, and more productive. In the previous study, it was reported that molecular docking was able to identify promising compounds that could be solutions in the health sector in the future, namely by predicting a ligand-receptor binding site model ${ }^{[15]}$. In this study, molecular docking is begun with the selection of protein as a target and ligands. These ligands were attached to the protein. The ligand structure of 1,5benzothiazepine and positive control (suramin) from ChemDraw was copied and pasted into the MOE program for then create a new database. Meanwhile, 3D protein crystallography extraction is available on the website www.rcsb.org/pdb in PDB format. 5GJB protein crystallography is carried out by deleting the native ligand on the protein structure. The main goal is to explore the potency of 1,5benzothiazepine chalcone derivative compounds to bind with the active site of the Zika virus helicase receptor. The water molecules in the protein must be removed, this is to avoid the bonding between these water molecules with the protein and it can interfere the data analysis ${ }^{[18]}$. The protein provided in protein databank, it needs to add the hydrogen atom to ensure that each atom in the molecule has a charge during receptor preparation ${ }^{[19]}$ because in general the interactions that occur between ligands and receptors are in the form of hydrogen bonds. Energy minimization is also important when preparing protein against alpha carbon, backbone atoms, and sidechain atoms to 
stabilize the bonds protein-ligand. The docking process is carried out for 10 times for each ligand in order to obtain the best binding free energy value $^{[20]}$. The docking results are presented in Table 2.

There are some parameters used to analyze the docking results such as Root Mean Square Deviation (RMSD), the docking method is valid if it has a RMSD less than $2 \AA^{[18]}$. The RMSD value describes the deviation value from errors that occur when docking. Smaller of the RMSD value indicated that the error deviation in the docking is also small. The binding free energy is useful for describing how the test ligand can binds well with the receptor. The lower value of the binding free energy is indicated that the binding between ligand and receptor is more stable ${ }^{[21]}$. Hydrogen bonding is also become parameter to select the best conformation of docking results. Generally, hydrogen bond can be defining as one of the most non-covalent bonds found in the biological systems ${ }^{[22]}$. This bonding occurs between positively charged hydrogen atoms and atoms that have high electronegativity such as $\mathrm{O}, \mathrm{N}$, and $\mathrm{F}^{[23]}$.

Tabel 2. Docking results

\begin{tabular}{|c|c|c|c|c|c|c|}
\hline \multirow[b]{2}{*}{ Code } & \multicolumn{6}{|c|}{ Parameter } \\
\hline & $\begin{array}{c}\text { Binding } \\
\text { Free Energy } \\
\text { (kcal/ mol) }\end{array}$ & RMSD & $\begin{array}{l}\text { Factor of Binding } \\
\text { with Suramin }\end{array}$ & Hydrogen Bond & $\begin{array}{l}\text { Van der Waals } \\
\text { Bond }\end{array}$ & $\begin{array}{l}\text { Hydrophobic } \\
\text { Bond }\end{array}$ \\
\hline MA1 & -4.7422 & 0.6881 & Lys607, His603 & Lys610 & Glu579, Glu611 & $\begin{array}{l}\text { Lys610, Lys607, } \\
\text { Lys616 }\end{array}$ \\
\hline MA2 & -4.3766 & 2.0469 & Arg388, Ala264 & Arg388 & - & Arg388, Arg226 \\
\hline MA3 & -4.6490 & 1.3074 & Asp574, Glu573 & Arg367, Glu573 & $\begin{array}{l}\text { Asp574, Asp602, } \\
\text { Glu573 }\end{array}$ & Arg367 \\
\hline MA4 & -4.7583 & 2.5208 & $\begin{array}{l}\text { Arg388, Asp291, } \\
\text { Ala264 }\end{array}$ & - & Asp291 & Arg226, Arg388 \\
\hline MA5 & -4.5734 & 1.3242 & $\begin{array}{l}\text { His603, Glu573, } \\
\text { Asp574 }\end{array}$ & Ser601 & Asp574, Glu573 & Arg367 \\
\hline MA6 & -4.2467 & 1.0413 & Asp574 & Asp574 & Asp574 & Arg367 \\
\hline MA7 & -4.5490 & 1.9705 & $\begin{array}{l}\text { His603, Glu573, } \\
\text { Asp574 }\end{array}$ & - & Asp574, Glu573 & Arg367 \\
\hline MA8 & -4.9291 & 1.4669 & $\begin{array}{l}\text { Glu573, His603, } \\
\text { Asp574 }\end{array}$ & Arg367 & $\begin{array}{l}\text { Glu573, Asp574, } \\
\text { Asp602 }\end{array}$ & Arg367 \\
\hline MA9 & -4.7536 & 0.9691 & - & Lys537 & - & $\begin{array}{l}\text { Lys537, Arg538, } \\
\text { Arg269 }\end{array}$ \\
\hline MA10 & -4.4337 & 0.7039 & Arg388, Lys389 & Arg388 & - & Arg388, Lys389 \\
\hline MA11 & -4.9251 & 1.4280 & - & Pro277 & Glu256, Asp259 & $\begin{array}{l}\text { Arg275, Arg242, } \\
\text { Arg218, Arg269 }\end{array}$ \\
\hline MA12 & -4.5822 & 3.4292 & - & - & - & $\begin{array}{l}\text { Arg538, Lys537, } \\
\text { Arg269 }\end{array}$ \\
\hline Suramin & -8.2270 & 4.6001 & - & Asp574, Lys389 & $\begin{array}{l}\text { Glu573, Asp574, } \\
\text { Asp291 }\end{array}$ & $\begin{array}{l}\text { Lys607, Lys389, } \\
\text { Arg388 }\end{array}$ \\
\hline $\begin{array}{l}\text { Native } \\
\text { Ligand }\end{array}$ & -8.9053 & 4.5597 & $\begin{array}{l}\text { Asp574, Glu573, } \\
\text { His603 }\end{array}$ & $\begin{array}{l}\text { Arg367, Arg343, } \\
\text { Asp574 }\end{array}$ & Glu573, Asp574 & $\begin{array}{l}\text { Arg367, Arg439, } \\
\text { Arg343 }\end{array}$ \\
\hline
\end{tabular}


In addition, hydrogen bonds can also be formed between the $\mathrm{H}$ atom with the phenyl ring contained in a medicinal compound ${ }^{[24]}$. There is also another binding such as van der Waals interaction and hydrophobic bonds which are supporting bonds to determine whether a compound has good activity or not.

Compounds MA3 and MA8 have the lowest binding free energy values. The smaller (negative) of the binding free energy value, it is indicated that, the smaller energy required for the ligand-protein interactions. So that the binding between ligand and protein become more stable and increased their predicted activity ${ }^{[25]}$. Two hydrogen bonds are formed in MA3 compound. Much more hydrogen bonds formed are predicted to increase the ligand activity as an inhibitor of the Zika virus helicase. In addition, these two compounds also have factor of binding (i.e., measure of probability that a tested compound will bind to the same amino acid residues to which the control compound, suramin binds) calculated by docking may predict which compounds will be more active Zika helicase inhibitors.

Compounds MA3 and MA8 were predicted to be active as inhibitors for Zika virus helicase, it was observed in their spatial arrangement using DSV as depicted in Figure 1. Superimposition describes the shape and the best poses of the ligand. It was seen from the compounds that overlap between the test compound and control positive compound.
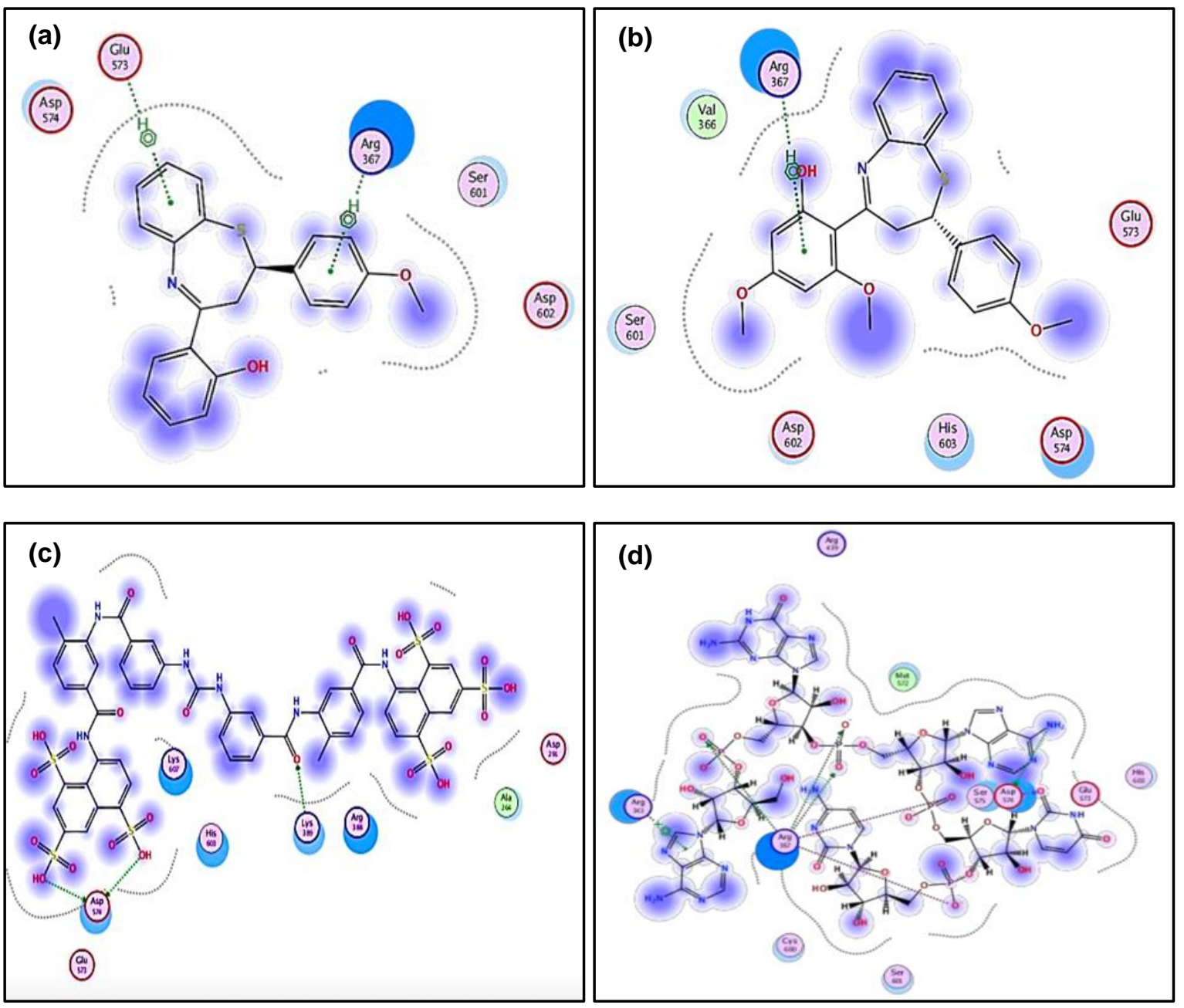

Figure 1. Visualization from ligand interactions of (a) MA3, (b) MA8, (c) native ligand and (d) suramin. 
From the superimposed results, it is found that MA3 and MA8 compounds have the same conformations and orientations with the native ligands in the 5GJB protein (i.e., Based on Figure 2), MA3 and MA8 compounds shown specificity with the hydrophobic amino acid residues and also hydrogen bonds through Arg367, Glu573 through van der Waals bonds. Thus, MA3 and MA8 compounds can inhibit the Zika virus helicase with the same mechanism as the native ligand.

MA3 and MA8 were exhibited crucial binding affinities (i.e. hydrogen bond) with residue
Arg367 at the protein active site which seems to be significant for activity prediction. Hence, MA3 and MA8 considered potentially active as ZIKV and can be further utilized in drug designing process.

MD simulation was applied to MA3 and MA8 to ensure that the interaction between ligand and protein are still maintained ${ }^{[26]}$. Visualization of the MD simulation are presented in Figure 3. The efficiency of hydrogen bonding for both of these compounds i.e., MA3 and MA8 were checked before and after MD simulation for 50 $\mathrm{ns}$ and $300 \mathrm{~K}$.
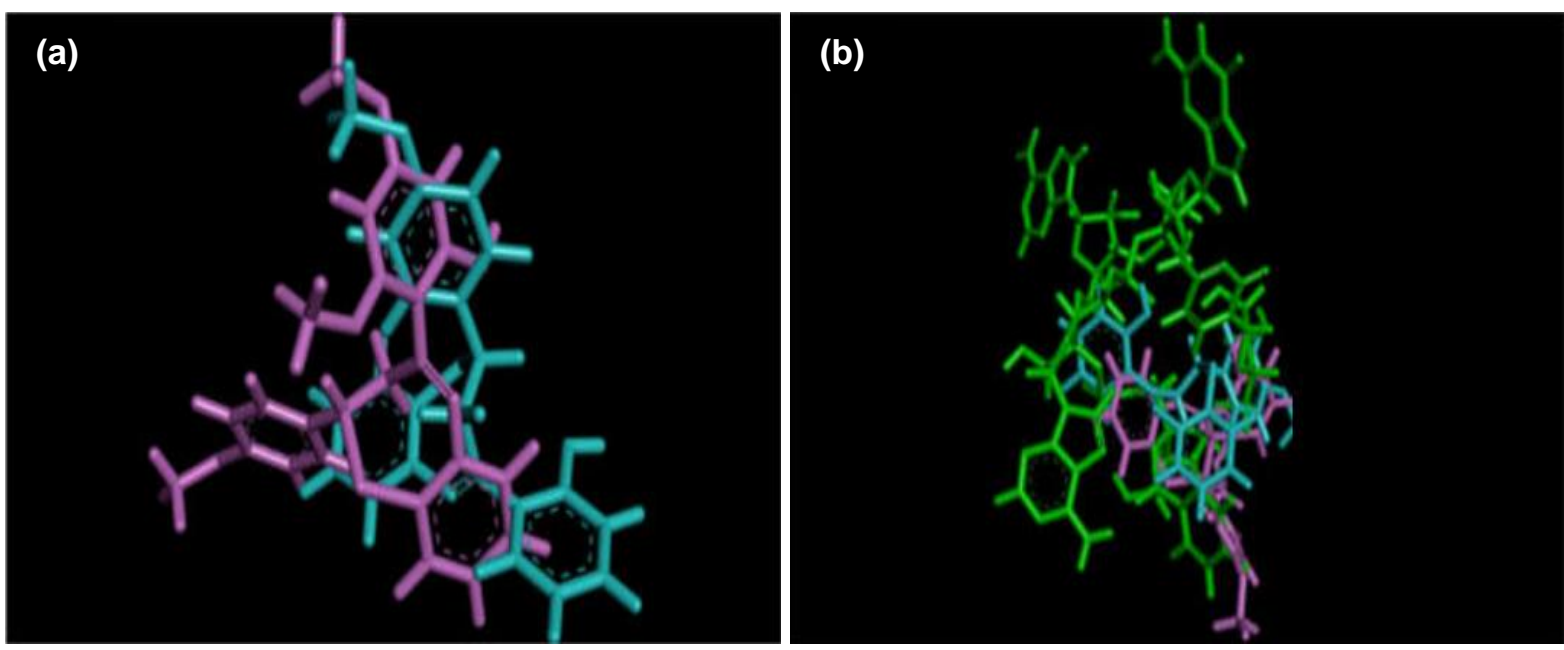

Figure 2. Superimposed (a) MA3 (blue) and MA8 (purple) (b) MA3, MA8, and Native Ligand (green) used DSV.
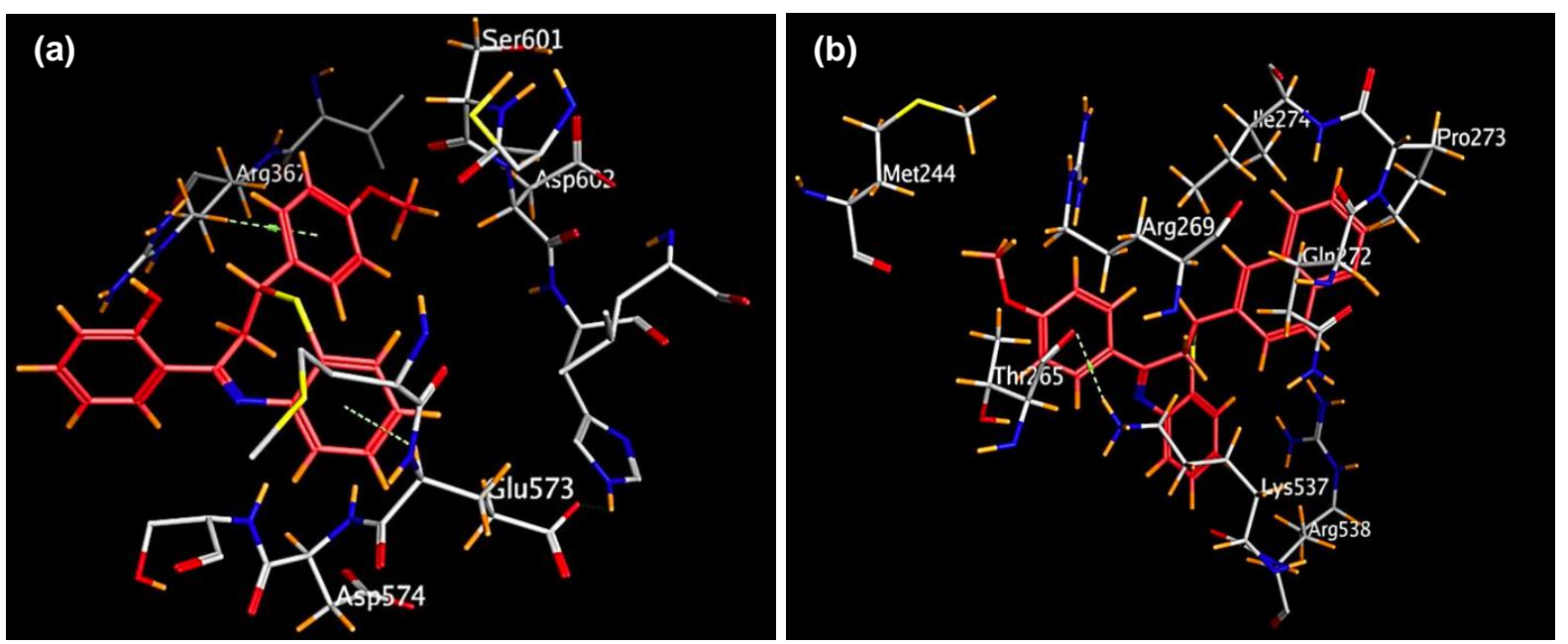

Figure 3. Visualization of MD simulation for compound (a) MA3 and (b) MA8. 
Based on the MD results, the conformation of MA3 and MA8 were maintained to bind well with same residues before and after MD simulation process. In addition, the existence of the hydrogen bond distance is less than $2.9 \AA$. It is indicated that both of these compounds can be used as potential inhibitor for Zika virus helicase.

\section{Conclusions}

MA3 and MA8 compounds have met all the expected docking parameters, besides that they also have a greater number of amino acid matches against positive control and also the lowest value of binding free energy compared than other compounds. These two compounds were also able to maintain the hydrogen bonding with the distances less than $2.9 \AA$. Furthermore, these two compounds can be used as an early stage for drug design and drug discovery against Zika virus helicase.

\section{References}

1. Newman, C., Friedrich, T. C. \& O'Connor, D. H., Macaque monkeys in Zika virus research: 1947-present. Curr. Opin. Virol., 25: 34-40 (2017).

2. Hamel, R., Dejarnac, O., Wichit, S., Ekchariyawat, P., Neyret, A., Luplertlop, N., Perera-Lecoin, M., et al., Biology of Zika Virus Infection in Human Skin Cells. J. Virol., 89(17): 8880-8896 (2015).

3. Tan, C. W., Sam, I. C., Chong, W. L., Lee, V. S. \& Chan, Y. F., Polysulfonate suramin inhibits Zika virus infection. Antiviral Res., 143(9): 186-194 (2017).

4. Quanquin, N., Wang, L. \& Cheng, G., Potential for treatment and a Zika virus vaccine. Curr. Opin. Pediatr., 29(1): 114-121 (2017).

5. Vyawahare, D., Ghodke, M. \& Nikalje, A. P., Green synthesis and pharmacological screening of novel 1,5-Benzothiazepines as CNS agents. Int. J. Pharm. Pharm. Sci., 2(2): 27-29 (2010).

6. Bajod, S. S., Synthesis and biological screening of some heterocycles derived from piperonal. Acta Chim. Pharm. Indica, 3(4): 261-267 (2013).

7. Mor, S., Pahal, P. \& Narasimhan, B., Synthesis, characterization, biological evaluation and QSAR studies of 11-psubstituted phenyl-12-phenyl-11a,12dihydro-11H-indeno[2,1-c][1,5]

benzothiazepines as potential antimicrobial agents. Eur. J. Med. Chem., 57: 196-210 (2012).

8. Gaikwad, S., Suryawanshi, V. S. \& Lohar, K., Synthesis and antimicrobial study of novel 2, 3-diydro-4-(naphtho [2, 1-b] furan2yl)-2-substitued $[1,5]$ benzothiazepines. J. Chem. Biol. Phys. Sci., 33(22): 936-940 (2013).

9. Garg, N., Chandra, T., Archana., Jain, A. B. \& Kumar, A., Synthesis and evaluation of some new substituted benzothiazepine and benzoxazepine derivatives as anticonvulsant agents. Eur. J. Med. Chem., 45(4): 1529-1535 (2010).

10. Dong, C. K., Urgaonkar, S., Cortese, J. F., Gamo, F.-J., Garcia-Bustos, J. F., Lafuente, M. J., Patel, V., et al., Identification and Validation of Tetracyclic Benzothiazepines as Plasmodium falciparum Cytochrome bc1 Inhibitors. Chem. Biol., 18(12): 1602-1610 (2011).

11. Di Santo, R. \& Costi, R., 2H-Pyrrolo[3,4-b] $[1,5]$ benzothiazepine derivatives as potential inhibitors of HIV-1 reverse transcriptase. Farmaco, 60(5): 385-392 (2005).

12. Ameta, K. L., Rathore, N. S. \& Kumar, B., Synthesis and preliminary evaluation of novel 1, 5-benzothiazepine derivatives as anti-lung cancer agents. Int. J. Pharm., 3(2): 328-333 (2013).

13. Badshah, S. L., Ahmad, N., Ur Rehman, A., Khan, K., Ullah, A., Alsayari, A., Muhsinah, A. Bin., et al., Molecular docking and simulation of Zika virus NS3 helicase. BMC Chem., 13(1): 67 (2019).

14. Ferreira, L., dos Santos, R., Oliva, G. \& Andricopulo, A., Molecular Docking and Structure-Based Drug Design Strategies. Molecules, 20(7): 13384-13421 (2015).

15. Yaeghoobi, M., Synthesis of chalcone-based 
six and seven membered heterocyclic compounds and their biological activities against H1N1 virus. University of Malaya, (2012).

16. Tian, H., Ji, X., Yang, X., Zhang, Z., Lu, Z., Yang, K., Chen, C., et al., Structural basis of Zika virus helicase in recognizing its substrates. Protein Cell, 7(8): 562-570 (2016).

17. Eryanti, Y., Zamri, A., Frimayanti, N., Teruna, H. Y., Supratmman, U., Herlina, T. \& Shiono, Y., Synthesis, Structure-Activity Relationship, Docking and Molecular Dynamic Simulation of Curcumin Analogues Against HL-60 for Anti Cancer Agents (Leukemia). Orient. J. Chem., 33(5): 2164-2172 (2017).

18. Purnomo, H., Kimia Komputasi Untuk Farmasi dan Ilmu Terkait. Pustaka pelajar, (2013).

19. Levita, J. \& Mustarichie, R., Pemodelan Molekul Dalam Kimia Medisinal. Graha Ilmu, (2012).

20. Syahputra, G., Ambarsari, L. \& Sumaryada, T., Simulasi docking kurkumin enol, bisdemetoksikurkumin dan analognya sebagai inhibitor enzim12-lipoksigenase. J. Biofisika, 10(1): 55-67 (2014).
21. Meiyanto, E., Docking kurkumin dan senyawa analognya pada reseptor progesteron: studi interaksinya sebagai selective progesterone receptor modulators (SPRMs). Pharmacon J. Farm. Indones., 13(2): 55-60 (2012).

22. Siswandono. \& Soekarjo., Kimia Medisinal Jilid II. Airlangga Univeristy Press, (2006).

23. Finch, C. A., Industrial water soluble polymers. Royal Society of Chemistry, (1996).

24. Schaefer, T., Wildman, T. A., Sebastian, R. \& McKinnon, D. M., The phenyl group as a hydrogen bond acceptor in 2-phenylphenol derivatives. Substituent comparisons. Can. J. Chem., 62(12): 2692-2696 (1984).

25. Suhud, F., Siswandono, S. \& Budiati, T., Sintesis dan Uji Aktivitas Senyawa 1Benzil-3-benzoilurea Tersubstitusi Bromo, Kloro, Floro dan Triflorometil pada posisi para sebagai Agen Antiproliferatif. Media Pharm. Indones., 1(3): 154-163 (2017).

26. Neni, F., Marzieh, Y., Hamid, N., Ihsan, I. \& Meysam, A., In silico studies and biological evaluation of chalcone-based 1,5benzothiazepines as new potential H1N1 neuraminidase inhibitors. J. Appl. Pharm. Sci., 10(10): 086-094 (2020). 